\title{
ARSITEKTUR MASJID MERAH PANJUNAN KOTA CIREBON
}

\author{
Architecture of Masjid Merah (The Red Mosque) in Panjunan, Cirebon
}

\author{
Oleh Hermana \\ Balai Peletarian Sejarah dan Nilai Tradisional Bandung \\ Jln. Cinambo No. 135 Ujungberung Bandung \\ Email: hermanacrb@ymail.com
}

Naskah Disetujui: 31 Mei 2012

\begin{abstract}
Abstrak
Perkembangan ajaran agama ditandai dengan adanya pembangunan tempat peribatannya. Cirebon yang terkenal dengan sebutan "kota wali" merupakan salah satu tongggak berkembangnya ajaran Islam di pantai utara wilayah Kerajaan Pajajaran. Pembangunan Masjid Merah yang diprakasai oleh Syekh Syarif Abdurrahman dibangun pada tahun 1480 Masehi. Bangunan Masjid Merah tidak terlepas dari seni arsitektur dengan segala ornamennya berbentuk piring porselin yang dipasang di dinding tembok dan juga terbuat dari susunan bata merah sehingga mesjid ini dinamakan Masjid Merah, serta didukung oleh tiga unsur kebudayaan besar. Saat ini Masjid Merah ditetapkan sebagai benda cagar budaya oleh Pemerintah Kota Cirebon. Sebagai benda cagar budaya perlu adanya pemeliharaan berkesinambungan yang diharapkan dapat dijadikan sebagai objek wisata sejarah dan budaya atau sebagai pembelajaran bagi generasi muda untuk menghormati karya leluhurnya. Penelitian ini bertujuan untuk memberikan data dan informasi di bidang kebudayaaan mengenai seni arsitektur Masjid Merah Panjunan di Cirebon. Metode yang digunakan dalam penelitian ini adalah deskriptif.
\end{abstract}

Kata Kunci : arsitektur, Masjid Merah.

\section{Abstract}

The development of religion is characterized by the construction of its place of worship. Cirebon which is known as the "city of wali" is a milestone in the development of Islam in the north coast area of the Kingdom of Pajajaran. The construction of Masjid Merah (the Red Mosque) was initiated by Syekh Syarif Abdurrahman in 1480 CE. The mosque was made of red bricks and has plates mounted on the walls as its ornament depicting harmony of three cultures which make it considered cultural heritage by local government. As the object of cultural heritage the mosque needs to be conserved for the benefit of historical and cultural tourism attraction or as learning experience for younger generation in respecting the work of their predecessors. This study aims to giving data and information in cultural area, especially architecture of the Red Mosque of Panjunan in Cirebon. The author conducts a descriptive-analytical method, and datat are obtained through primary and secondary sources.

Keywords: architecture, the Red Mosque. 


\section{A. PENDAHULUAN}

Dalam sejarah perkembangan Islam di Pulau Jawa, khususnya daerah Cirebon mengalami perjalanan yang panjang dan berliku, karena Cirebon masih berada di bawah kekuasaan Pajajaran. Awal masuknya Agama Islam di daerah Cirebon ditandai dengan adanya pesantren di Pedukuhan Amparan Jati. Pesantren tersebut dipimpin oleh ulama besar bernama Syekh Dathul Kahfi. Sebagai sarana peribadatan umat Islam, para wali membangun masjid dan surau. Pembangunan masjid yang pertama berada di kompleks Dalem Agung Pakungwati Keraton Kasepuhan yang bernama Tajug Pejlagrahan termasuk ke dalam wilayah administratif Kampung Siti Mulya. Dalam perkembangan selanjutnya, pembangunan masjid yang kedua adalah Masjid Merah Panjunan. Masjid ini dibangun sebelum masjid Agung Sang Cipta Rasa dibangun oleh para wali.

Dibangunnya Masjid Merah Panjunan atas inisiatif dari imigran Arab (Bagdad, Irak) yang datang ke daerah Cirebon sekitar abad ke-14 M, setelah mendapat restu dari Pangeran Cakrabuana sebagai penguasa Cirebon. Pembangunan masjid ini dianggap perlu dalam pengembangan syariat Islam di wilayah Cirebon.

Dalam rombongan imigran Arab terdapat orang yang bernama Syarif Abdurakhman yang kemudian berguru Agama Islam kepada Syekh Dathul Kahfi di Pasambangan Amparan Jati. Dalam perjalanan hidupnya Syekh Abdurakhman diterima oleh Pangeran Cakrabuana, selanjutnya diperintahkan untuk membangun daerah yang sekarang dikenal dengan nama Panjunan. Pada tahun 1480 Syekh Syarif Abdurakhman membangun masjid di daerah tersebut dengan nama Masjid Merah Panjunan. Masjid ini dinamakan Masjid Merah Panjunan karena dibangun dengan susunan bata merah dan terletak di daerah Panjunan. Pada tahun 1549 oleh Panembahan Ratu, masjid ini diperbaiki dengan membuat pagar kuta kosod. Pada pintu masuk dibangun sepasang Candi Bentar dan panel pintu jati berukir, kemudian pada dinding masjid luar dan dalam terdapat hiasan dari piring keramik/porselin yang ditengarai berasal dari Negeri Cina (Disbudpar, 2006: 21).

Pembuatan suatu bangunan tidak terlepas dari teknik pembuatan bangunan itu sendiri, yang kemudian dikenal dengan nama seni arsitektur. Seni arsitektur Masjid Merah Panjunan didukung oleh adanya pengaruh tiga unsur kebudayaan yang besar, yaitu budaya lokal, Arab, dan Cina. Perpaduan ini akan menghasilkan suatu makna yang mendalam yang ada dalam prinsip-prinsip ajaran Islam. Sebuah karya arsitektur dapat menyimak pesan yang ada di balik susunan meterial bangunan tersebut.

Secara umum penelitian ini bertujuan untuk memberikan data dan informasi kebudayaan bagi keperluan pelaksanaan kebijakan pembangunan di bidang kebudayaan dan kemasyarakatan. Sedangkan tujuan khususnya adalah memperoleh data dan informasi mengenai seni arsitektur Masjid Merah Panjunan di Kota Cirebon, kemudian mendokumentasikan dan menginformasikan langsung kepada masyarakat.

Lokasi penelitian dilakukan di Masjid Merah Panjunan yang terletak di RW 08 RT 02 Kampung Panjunan, Kelurahan Panjunan, Kecamatan Lemahwungkuk, Kota Cirebon. Penelitian Arsitektur Masjid Merah Panjunan Cirebon dengan dibatasi pada hal-hal yang menyangkut asal bahan bangunan, fungsi dan makna ornamen, teknik pembuatan dan gaya bangunan. Dengan demikian diharapkan dapat mengungkapkan gambaran secara umum mengenai arsitektur pembuatan Masjid Merah Panjunan Cirebon. 
Sebelum melakukan penelitian di lapangan dilakukan studi pustaka dengan membaca dan mencatat hal-hal yang dapat dijadikan sebagai referensi penelitian ini. Metode penelitian yang digunakan dalam penelitian ini adalah metode kualitatif dengan melakukan wawancara mendalam dengan beberapa orang informan, seperti tokoh masyarakat dan penduduk yang bersangkutan. Selain itu digunakan metode kuantitatif dalam menjaring data kependudukan seperti jumlah penduduk menurut jenis kelamin laki-laki dan perempuan, jenis mata pencaharian, agama yang dianut dan karakteristik lain dari masyarakat setempat. Untuk mendapatkan data yang tidak terjaring dalam wawancara, maka dilakukan metode pengamatan atau observasi.

\section{B. HASIL DAN BAHASAN}

Secara administratif, Kota Cirebon merupakan salah satu dari 25 kabupaten/kota di Jawa Barat, yang terdiri atas 5 wilayah kecamatan, 22 kelurahan, 247 Rukun Warga, dan 1.357 Rukun Tetangga. Batas-batas wilayahnya adalah: sebelah timur berbatasan dengan Laut Jawa, sebelah selatan, barat, dan utara dengan Kabupaten Cirebon. (BPS Kota Cirebon, 2010).

Kota Cirebon yang memiliki luas $37,358 \mathrm{~km}^{2}$ terletak antara $108^{\circ} 35^{\prime}-108^{\circ}$ 36' Bujur Timur dan $9^{\circ} 30^{\prime}$ Lintang Selatan. Curah hujan rata-rata $107 \mathrm{~mm}$ per tahun. Topografi wilayahnya sebagai berikut: landai ke arah utara dengan kemiringan $0-5 \%$, serta ketinggian di atas permukaan laut antara 0-120 m (makin tinggi ke arah selatan). Bagian utara dan timur mempunyai ketinggian 0-3 m, sedangkan bagian barat daya berketinggian rata-rata $5 \mathrm{~m}$. Kota Cirebon merupakan penghubung antara Jakarta menuju ke arah timur (Jawa Tengah/Jawa Timur).

Dengan luas wilayah $\pm 6,507 \mathrm{~km}$, Kecamatan Lemahwungkuk memiliki jumlah penduduk 52.811 orang dengan kepadatan 8.116 per $\mathrm{km}^{2}$ (BPS Kota Cirebon, 2010). Panjunan adalah salah satu Kelurahan yang terdapat di wilayah pemerintahan Kecamatan Lemahwungkuk kota Cirebon. Kelurahan ini terletak di bagian Selatan wilayah Kecamatan Lemahwungkuk dan berbatasan langsung dengan Kecamatan Pekalipan. Kelurahan Panjunan merupakan sebuah daerah perumahan dan jasa perdagangan. Kelurahan ini terletak di daerah sebelah selatan-timur Balaikota Cirebon. Kelurahan Panjunan berbatasan, sebelah utara dengan Kelurahan Kebonbaru, sebelah selatan dengan Kelurahan Lemahwungkuk, sebelah barat dengan Kelurahan Pekalangan, dan sebelah timur dengan Laut Jawa.

Pemerintah Kelurahan Panjunan yang berada di Kecamatan Lemahwungkuk dengan luas $1,28 \mathrm{~km}^{2}$, meliputi 10 Rukun Warga (RW), 40 Rukun Tetangga (RT), dengan jumlah penduduk 9.981 Jiwa (Monografi Kelurahan Panjunan, 2010).

Sebagian besar atau 95\% masyarakat Kelurahan Panjunan memeluk agama Islam dan sisanya sekitar 5\% memeluk agama Kristen sebanyak 1.421 orang, Katholik sebanyak 1.018 orang, dan Hindu-Budha sebanyak 416 orang, dan penganut kepercayaan sebanyak 53 orang. Kerukunan hidup beragama dapat terjalin baik, saling menghargai dan menghormati antara sesama pemeluk agama. Dalam upaya meningkatkan kehidupan beragama di Kelurahan Panjunan telah tersedia sarana peribadatan agama Islam, yaitu 12 masjid dan 28 mushola, sedangkan sarana peribadatan agama Budha, Kristen, Protestan dan Katholik melakukan kegiatan ibadahnya yang terdapat di dalam/di luar lingkungan kelurahan Panjunan.

Semenjak perintah shalat diterima lewat Isra Mi'raj Nabi Muhammad Saw., masjid menjadi tempat sentral pengembangan syariat Islam. Secara lahiriah masjid memang mengekspresikan prosesi dan pola laku ibadah shalat 
terutama shalat berjamaah. Seiring dengan keterampilan membangun, penampilan arsitektur masjid semakin terbuka untuk memenuhi tuntutan ekspresi pola baku prosesi ibadah. Dalam tradisi budaya Islam, basis perwujudan seni dan arsitektur adalah rekayasa pemahaman mistik. Penampilan ornamen masjid dibatasi dengan larangan mengekspresikan benda berjiwa, satuan tugasnya kemudian dicurahkan untuk mencapai transformasi kesemestaan pada sejumlah pertanda keesaan Allah SWT. (Fanani, 2008: 110 ).

Karya arsitektur dapat menyimpan makna yang ada di balik susunan material bangunan. Bangunan surau akan menandai adanya kehidupan Islam di tempat itu. Kelenteng di tengah perkampungan mengisyaratkan bahwa ada kehidupan etnik Cina di sekitarnya. Melihat Borobudur dapat diperoleh gambaran bahwa di daerah sekitarnya pada masa lalu terdapat masyarakat penganut agama Budha. Melihat bangunan Pura dapat tergambarkan kehidupan masyarakat penganut agama Hindu.

Arsitektur mengembangkan dirinya untuk memenuhi kebutuhan-kebutuhan fisik dan sekaligus metafisik, memenuhi unsur raga maupun kejiwaan masyarakat. Keindahan arsitektur menggambarkan perasaan emosional, intelektual seraya menuntun ke arah perenungan. Bentuk arsitektur bangunan adalah rajutan makna dari rujukan dasar mitologi, ritual, hingga doktrinal. Seni arsitektur mencerminkan tingkat penguasaan masyarakat terhadap pengetahuan. Masyarakat yang masih dikuasai oleh alam, akan cenderung menerima bentuk-bentuk dan bahan-bahan yang murni alami. Sementara masyarakat yang mulai mengembangkan teknologi untuk mengatasi alam cenderung pula pada bahan dan bentuk turunan alam maupun olahan mereka sendiri. Bentuk bulatan yang tak harus sempurna, bahan kayu, batu, cenderung diminati oleh yang pertama. Sementara yang kedua lebih dekat kepada geometri ketat: bulatan sempurna, persegi, bujur sangkar, segitiga dan turunannya, maupun bahan olahan seperti plaster, beton, kaca. Di sinilah peran ilmu pengetahuan baik di bidang matematika, planimtri, astronomi, kimia, dimanfaatkan (Fanani, 2008:14).

Pengetahuan arsitektur terus berkembang, seiring dengan keadaan masyarakat yang semakin maju, serta pemahamannya mencakup banyak hal, semenjak kajian tentang struktur, konstruksi bahan, fisika terapan: hawa, cahaya, suara, sampai ke tata cara merancang hingga mengoperasikan bangunan. Cara pendekatan untuk menghasilkan karya arsitektur pun ikut terpengaruh. Para arsitek sangat terbiasa bergaul dengan konsep, fungsi, gambar, dan garis sebagai alat pendekatan dalam menyusun rancangan karyanya. Meskipun banyak di antara para arsitek yang menerjemahkan pengertian-pengertian alat tersebut secara kuantitatif, tetapi terdapat pula beberapa tokoh yang mencoba bergerak dari wilayah kuantitatif dan sangat sadar bahwa bobot karyanya justru sangat ditentukan dari keberhasil-annya mengolah sisi kualitatif itu pada perwujudan fisik.

Sebuah karya arsitektur barulah menjadi bermakna ketika fungsi-fungsi yang dikandungnya, baik fungsi fisik maupun fungsi nonfisiknya dapat dikoordinasikan secara terpadu, tidak ditangkap secara terpisah-pisah. Dengan demikian, maka semua kaitan erat antara gagasan-gagasan kehidupan, perilaku masyarakat dan kedudukan tampilan benda budaya sekaligus dalam sebuah sistem terpadu telah menjadi jelas posisinya.

Arsitektur masjid dapat menggambarkan keadaan suatu masyarakat muslim, situasi kemasyarakatan, pemahaman keagamaan, saat dan tempat dimana karya arsitektur masjid tersebut berada. Arsitektur masjid sebagai benda bentukan dengan sendirinya akan bisa menuntun pada penjelasan tentang pola perilaku, kehendak, keinginan, dan gagasan kea- 
gamaan masyarakat muslim di sekeliling masjid tersebut. Karya arsitektur tidak akan lepas sendiri dari keadaan masyarakat yang melahirkannya. Sebuah karya arsitektur akan menjadi pintu masuk untuk memahami keadaan masyarakat setempat di tempat bangunan itu berada. Fakta fisik arsitektur Masjid Demak, dengan corak atap tajuknya, sengkalan memet berupa binatang bulus berkaki empat dan ekornya, digabung dengan sumber historiografi Jawa baik lisan maupun tertulis, akan menuntun lebih jauh pada gambaran suasana kemasyarakatan di awal perkembangan Islam di Jawa. Hal ini pun berlaku pada masjid di Cirebon, seperti Masjid Pejlagrahan, Masjid Sang Cipta Rasa dan Masjid Merah di Panjunan. Masjid-masjid ini berada pada lingkaran awal-awal penyebaran Islam di Tatar Sunda.

Ketika gerakan arsitektur giat dalam pembangunan masjid dan gelombang kerajinan serta olah seni bahan, serta memacu pertumbuhan tradisi dekoratif atau ornamentalitas, semua itu adalah cerminan dari yang tengah berkembang pada kehidupan masyarakat muslim pada umumnya. Dengan demikian perkembangan seni dekoratif atau ornamen bukan hanya sebatas yang dikembangkan di wilayah Persia, Asia Tengah atau pun hingga ke wilayah Hindustan (India) yang banyak dipengaruhi oleh budaya agama Budha dan Hindu. Akan tetapi, 7 abad kemudian setelah Nabi Muhammad Saw. wafat, pembangunan masjid di wilayah Nusantara terinspirasi dengan seni dekorasi Timur Tengah (Persia), Hindu, Cina, dan budaya lokal, semua memperkokoh sosok tampilan ornamen arsitektur Islam. Seperti halnya Masjid Kudus yang dibangun oleh Jakpar Sodiq bergelar Sunan Kudus mempunyai arsitektur bergaya Hindu-Jawa yang berada di Kota Kudus, Masjid Demak di Kota Demak, dan di Cirebon sendiri terdapat bangunan Masjid Agung Sang Cipta Rasa yang dibangun semasa Syekh Syarif Hidayatullah dan dibantu oleh para wali dengan berbagai latar belakang kehidupannya sehingga mempunyai bentuk

arsitektur seperti sekarang, Tajug Pejlagrahan yang dibangun oleh Pangeran Cakrabuana dengan berbagai dekorasi sangat sederhana, Masjid Merah Panjunan yang dibangun oleh Syekh Abdurakhman dengan latar belakang dari Negeri Bagdad (Irak) arsitekturnya dibangun atas budaya Persia, Cina, dan lokal.

Masjid menjadi salah satu karya teragung dari Nabi Muhammad Saw. dari dalam masjidnya, keteladanan sosial dengan kedisiplinan serta etika yang luhur diajarkan kepada para pengikutnya. Nabi Muhammad Saw. mengajarkan shalat berjamaah menjadi media untuk mengendalikan kebiasaan-kebiasaan buruk suku Arab dengan cara latihan untuk bersikap, bersujud secara teratur dan penuh ketertiban.

Prinsip membangun masjid di tengah pembentukan masyarakat yang diletakkan Rasulullah Saw., dilanjutkan oleh pemimpin umat dengan prinsipprinsip membuat bangunan. Para pemimpin muslim semenjak awal pemerintahan khalifah, telah menafsirkan ayat-ayat Al-Qur'an untuk diramu menjadi doktrin pembangunan yang memerintahkan untuk menerima muatan lokal sejauh tidak bertentangan dengan prinsipprinsip nilai, moralitas, etika, serta aturan Islam. Fakta bagaimana mereka memberi tafsir pada QS Al-A'raaf: 99, yang kemudian memandu perkembangan arsitektur Islam. Setelah ajaran Islam berkembang di Nusantara dari Samudra Pasai kemudian berkembang ke daerah Gresik (Jawa Timur) sampai pula ke Cirebon, maka para ulama memerlukan sarana untuk syiar Islamnya, salah satunya adalah pembangunan masjid.

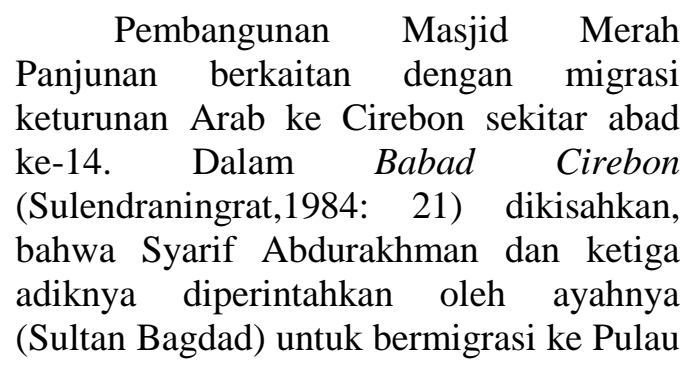


Jawa. Mereka adalah Syarif Abdulrakhim, Syarif Kafi, dan Sarifah Bagdad. Daerah tujuan mereka adalah Cirebon. Di Cirebon mereka berguru kepada Syekh Nurjati di Pasambangan Gunungjati. Oleh Syekh Nurjati mereka diperkenalkan kepada Pangeran Cakrabuwana (Ki Kuwu Cerbon). Pangeran Cakrabuwana menerima mereka dengan baik, dan menyuruh Syekh Abdurakhman untuk membangun pemukiman yang sekarang dikenal dengan nama Panjunan, sedangkan Syekh Syarif Abdurakhim membangun pemukiman yang sekarang dikenal dengan nama Kejaksan. Syarif Abdurakhman dikenal dengan nama Pangeran Panjunan, sementara Syekh Syarif Abdurakhim dikenal dengan nama Pangeran Kejaksan.

Selain melakukan syiar Islam di daerah pemukiman baru, Syarif Abdurakhman juga mengembangkan pembuatan peralatan rumah tangga dari tanah liat atau gerabah atau di sebut Anjun. Pada masa kesultanan Cirebon, daerah ini merupakan pusat pembuatan gerabah, di kemudian hari daerah ini dikenal dengan nama Panjunan.

Masjid Merah Panjunan terletak di Jl. Kolektoran, Kelurahan Panjunan, Kecamatan Lemahwungkuk, Kota Cirebon. Masjid yang berdiri di perkampungan Arab ini telah berumur sekitar 532 tahun. Pada tahun 1480 Pangeran Pajunan membangun surau ini, yang kemudian terkenal dengan nama Masjid Merah Panjunan. Surau berukuran sekitar $150 \mathrm{~m}^{2}$ ini dibangun 18 tahun sebelum pembangunan Masjid Agung Sang Cipta Rasa. Dengan demikian surau ini menjadi tempat ibadah kaum muslimin kedua setelah Tajug Pejlagrahan di Kampung Sitimulya (kompleks Keraton Kesepuhan). Masjid ini dikenal dengan nama Masjid Merah, karena dinding mesjid ini dibangun dari susunan bata merah, sementara nama Panjunan menunjuk pada nama kampung tempat masjid ini berada.
Pada masa pemerintahan Sunan Gunungjati, surau ini sering digunakan untuk pengajian dan musyawarah Wali Sanga. Ketika Kesultanan Cirebon diperintah oleh Panembahan Ratu (Cicit Sunan Gunungjati), sekitar tahun 1549, halaman masjid dipagar dengan kuta kosod. Pada pintu masuk dibangun sepasang candi bentar dan pintu panel jati berukir. Sekitar tahun 1978 masyarakat setempat membangun menara pada halaman depan sebelah selatan, sementara candi bentar dan pintu panel dibongkar (Disporbud, 2006: 21 ).

Bangunan Masjid Merah Panjunan merupakan unsur universal dari arsitektur yang tidak bisa dipisahkan antara satu unsur dengan yang lainnya. Bangunan terdiri atas ruang utama masjid sebelah barat yang hanya dibuka untuk jamaah pada waktu sholat Idul Fitri dan sholat Idul Adha, pada hari biasa ruangan tersebut ditutup. Ruang utama masjid dengan ruang lainnya (sebelah timur) dibatasi tembok yang terbuat dari bata merah, dan ruangan ini yang dipakai pada hari-hari biasa sholat para jamaah. Sebelah selatan dari bangunan utama terdapat ruangan imam masjid. Kemudian di sebelahnya ada makam salah satu pendiri masjid, ruangan tempat bedug dan kohkol, ruang bekas bangunan menara, dan di samping kiri ada pintu yang tingginya tidak lebih dari 150 $\mathrm{cm}$ untuk masuk jamaah. Ruang sebelah utara merupakan ruang bekas tempat wudhu, sebelum dipindahkan sedikit lebih ke depan ada sebuah sumur. Bagian depan bangunan dikelilingi tembok atau yang disebut dengan kuta kosod, sedangkan pintu masuk dipagar dengan pintu besi. Pada bangunan-bangunan tersebut terdapat ornamen atau ragam hias yang memiliki makna atau simbol yang sampai kini masih dianggap dan dipercaya oleh para pendukungnya. 


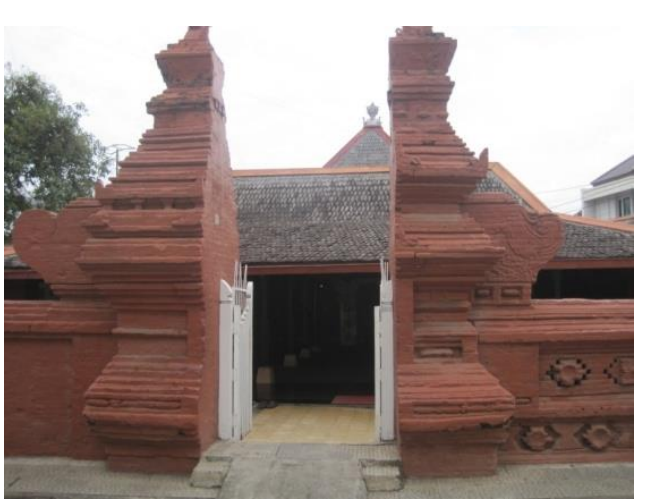

Foto 1. Masjid Merah tampak depan.

(Sumber: Dok. Pribadi, 2011)

Jika dilihat dari struktur bangunan tembok atau kuta kosod yang mengelilingi Masjid Merah, sangat jelas bahwa corak bangunan seperti ini dipengaruhi oleh kepercayaan agama Hindu. Bangunan tersebut mirip dengan bangunan pura-pura sebagai tempat ibadah agama Hindu. Selain itu, juga sangat mirip dengan candicandi Hindu yang ada di Jawa. Pembangunan kuta kosod dengan ciri candi bentar yang diprakasai oleh cicit Sunan Gunung Jati, artinya mengisyaratkan bahwa para pemeluk agama Islam sangat toleran terhadap para pemeluk agama lain. Hal ini tidak terlepas dari cara dakwah para wali dalam menyiarkan ajaran Islam. Mereka sangat menghormati hasil budaya masyarakat sebelum Islam datang. Hasil budaya masyarakat yang sudah ada, baik berupa kesenian, seni bangunan, dan ada istiadat yang ada dibiarkan terus berkembang, kemudian disisipi dengan ajaran Islam. Budaya yang tidak sesuai dengan ajaran Islam lambat-laun akan hilang dengan sendirinya.

Pada awal pembangunan Masjid Merah hanya mempunyai satu pintu masuk, yang sekarang menjadi tempat pengimaman (mihrab), kemudian setelah pembuatan kuta kosod, pintu masuk untuk jamaah ditambah 2 pintu, satu sebelah selatan dan satu lagi sebelah timur. Satu pintu sebelah timur memakai pagar besi (Foto: 1), sedangkan pintu sebelah selatan ditutup dengan pintu kayu dan tingginya hanya 1,5 m. Jadi jika jamaah akan masuk masjid harus menundukkan kepala. Makna yang terkandung dalam pembuatan pintu ini adalah agar manusia bersifat tawadhu, merendahkan diri di hadapan Allah SWT. Dengan menundukkan kepala dalam memasuki masjid ini, para wali secara tidak langsung mengajarkan kepada kita selaku umat sesudahnya, agar menghormati tempat tersebut sebagai tempat suci. Sebagai tempat berserah diri, berdoa, dan mendekatkan diri kepada-Nya.

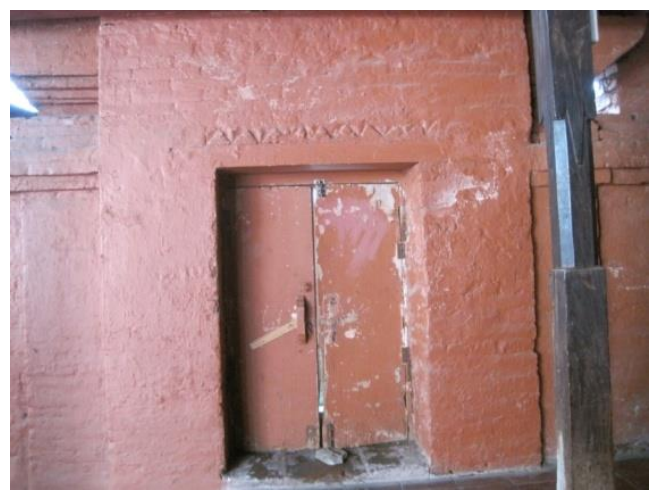

Foto 2. Pintu masuk sebelah selatan.

(Sumber: Dok. Pribadi, 2011)

Pembangunan Masjid Merah Panjunan mempunyai unsur arsitektur yang universal. Unsur universal dalam masjid dimaksudkan sebagai bentuk tampilan yang telah baku disepakati oleh umat Islam sebagai tampilan sebuah masjid. Hal pokok yang perlu diingat adalah bahwa sebuah masjid hadir untuk menampung keperluan ibadah sholat berjamaah. Dengan demikian tentulah beberapa unsur universal tersebut perlu memenuhi tuntutan syarat rukun ibadah shalat berjamaah. Arah Kiblat dan posisi imam serta makmum adalah pokok utama yang harus dipenuhi. Unsur lain seperti tempat wudhu, menara, mimbar adalah kelengkapan sekunder, bukan yang wajib diadakan. Dalam sunnah Rasul Saw. memang tercatat betapa di dalam masjidnya terdapat sebuah sumur di halaman yang menjadi tempat para jamaah melaksanakan wudhu. Rasul Saw. pernah memerintahkan Bilal r.a mengambil posisi yang tinggi di salah satu dinding pembatas 
masjidnya untuk menyeru panggilan Azan yang disebut menara.

Mimbar pun datang menyusul kemudian ketika para jamaah merasa perlu agar Rasul Saw. berada sedikit lebih tinggi ketika berkhutbah di dalam masjidnya, supaya mereka yang mendapat tempat di belakang dapat melihat lebih jelas wajah Rasulullah. Jadi kedudukan hukum bendabenda ini sebatas sunah. Apabila kubah, kaligrafi, muqarnas, maskura, tidak ada dalam arsitektur masjid, tidak berpengaruh terhadap syarat sah atau tidaknya shalat. Dalam ibadah, Islam sangat luwes dan sangat minimal mensyaratkan penyediaan fasilitas.

Kecepatan ekspedisi umat Islam dalam mengembangkan Islam telah menuntun dalam bentuk budaya yang sangat toleran terhadap ekspresi lokal. Bentuk budaya lokal termasuk arsitektur banyak diambil menjadi khazanah atribut sekunder Islam. Bentuk-bentuk itu disempurnakan dengan memberi pemaknaan baru seraya terus-menerus mengembangkannya menjadikan bernafaskan doktrin Islam. Dalam perjalanan pertumbuhan atribut sekunder kebudayaan masyarakat muslimin, memberikan hubungan prosesi ibadah sholat berjamaah dengan kehadiran elemen arsitektur sebagai ekspresinya. Untuk arsitektur masjid, yang terpokok dalam prosesi shalat berjamaah: imam dan makmum, beserta prosesi ibadah lainnya: wudhu, azan, dan khutbah. Unsur-unsur tersebut terpadu dalam satu rangkaian perwujudan arsitektur. Ruang imam ditandai dengan kehadiran mihrab. Untuk ruang makmum, ruang utama jamaah, biasa disebut haram atau zulla, bisa juga melebar ke serambi. Mimbar diposisikan bagi pemberi khutbah. Menara adalah atribut tempat muazin melantunkan panggilan azan. Untuk membedakan posisi imam, pada dinding arah ke kiblat ditandai dengan mihrab. Di bagian atas bangunan di atas ruang mihrab ditambah kubah. Mimbar ditempatkan di sisi kanan di samping mihrab (apabila para jamaah menghadap ke arah kiblat) atau bahkan di dalam mihrab itu sendiri.

\section{Kubah}

Kubah memiliki bentuk yang banyak ragamnya. Sebagian dinasti penguasa muslimin menyumbangkan bentuk tipologinya. Terdapat beberapa macam kubah, di antaranya adalah Kubah Persiani, Kubah Usmani, dan bentuk kubah yang diambil dari budaya lokal.

Bentuk kubah yang ada di Masjid Merah Panjunan bentuknya merupakan bentuk piramida. Bentuk ini mengilhami bentuk piramida yang ada di Mesir. Makna dari ciri bentuk kubah seperti ini adalah sesuatu yang mempunyai nilai keabadian, dengan menjunjung tiang penyangga surga. Bentuk kubah Masjid Panjunan kemudian diadopsi oleh pembangunan Masjid Agung Sang Cipta Rasa Cirebon, hanya saja di atas bentuk kubah tidak terdapat memolo.

Penafsiran kembali diagram pendekatan kerucut peningkatan ruhani, apabila ditransformasikan pada perwujudan yang memungkinkan untuk dikontruksikan, menghasilkan penyederhanaan bentuk dari kerucut kepiramidaan peningkatan ruhani (Fanani, 2008:129). Pada diagram piramida inilah dapat disusun gambaran tahap pencapaian tingkat keruhanian tersebut, yang bersesuaian dengan konsepsi ahwal dan maqomat. Seluruh jumlah tingkat keruhanian dalam konsepsi ahwal dan maqomat sangat bervariasi bergantung pada aliran pemahaman sufi yang berkembang. Dalam garis besar jumlah itu bergerak antara empat puluh tingkatan dengan pengelompokan pada tiga sampai tujuh tahapan. Tahap-tahap inilah kemudian ditransformasikan ke bentuk arsitektur berupa bentukan masa bangunan maupun hierarki ruang-ruang baik secara vertikal atau horizontal. 


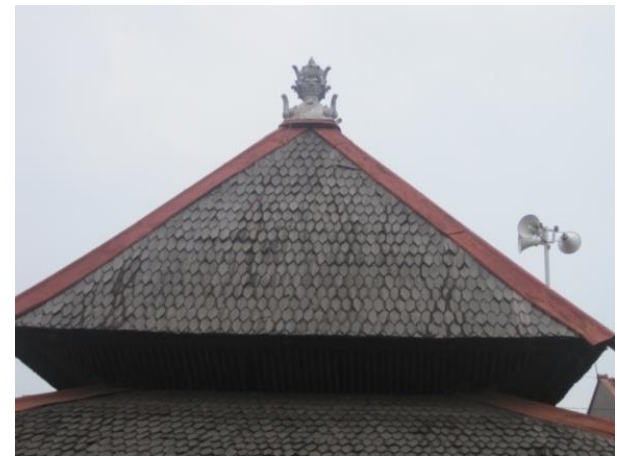

Foto 3. Kubah Masjid Merah

(Sumber: Dok. Pribadi, 2011).

Di atas kubah Masjid Merah yang berbentuk piramida terdapat memolo dengan gaya mahkota raja. Ornamen memolo atau kepala biasanya pada bangunan masjid, tajug dan mushola. Menurut beberapa keterangan terdapat dua jenis ornamen memolo, pertama, bentuk memolo yang berasal dari mahkota raja, dan kedua merupakan corak dari berbagai floral atau dedaunan. Bentuk memolo yang digunakan pada Masjid Merah ini berasal dari perwujudan mahkota raja, awalnya diambil dari cerita dunia pewayangan yang mengandung unsurunsur kehinduan. Hal ini bisa dimengerti karena sebelum masuknya Islam ke tanah Jawa, pengaruh ajaran agama HinduBudha telah menjadi anutan masyarakat Jawa pada umumnya. Bentuk memolo seperti ini (mahkota raja) kemungkinan hanya ada di masjid-masjid Nusantara saja, karena masjid-masjid di Timur Tengah, India, atau pun Cina biasanya di atas struktur kubah ditempatkan memolo yang berbentuk runcing seperti jarum.

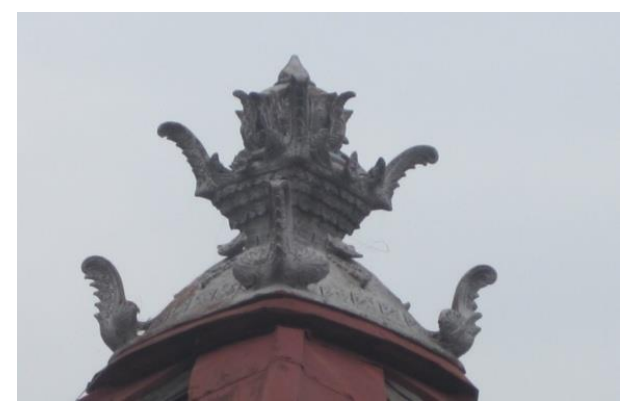

Foto 4. Memolo Masjid Merah. (Sumber: Dok. Pribadi, 2011)
Seperti bangunan-bangunan lama lainnya, Masjid Merah memakai atap dengan bahan sirap. Pada tahun 2001-2002 atap sirap direnovasi oleh Dinas Pariwisata Provinsi Jawa Barat. Pemakaian atap sirap khususnya di daerah Cirebon bisa dilihat pada bentuk bangunan Masjid Agung Sang Cipta Rasa, Masjid Gunungjati, dan Masjid Buyut Trusmi. Struktur bangunan atapnya memakai pola berundak, dan pola ini sama dengan pola Masjid Agung Sang Cipta Rasa.

Susunan atap, berbentuk piramida atau pun kubah tersusun secara hierarkis mewujudkan dominasi kesan kesatuan tersebut. Dominasi puncak atap menjadi tumpuan perhatian. Struktur utama yang mendukung keberadaan atap ini dapat dikatakan menjadi bagian pokok dari perhatian di dalam ruangan. Hubungan antara elemen digarap dengan saksama, perpindahan dari bentuk kubah, lingkaran, segi delapan, segi empat, di samping membuat alasan logis bagi kaidah mekanika beban dan gaya, sekaligus juga menampilkan cerminan hierarki keberadaan dan keteraturan antarunsur. Pilihan terhadap bentuk geometrik yang ketat menjadi pendukung tema utama, di mana ekspresinya terasa pas bagi perwujudan prinsip-prinsip keteraturan.

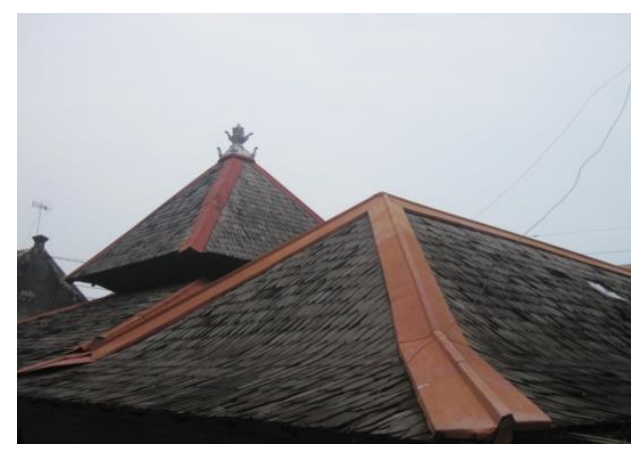

Foto 5. Atap Sirap Masjid Merah (Sumber: Dok. Pribadi, 2011)

\section{Mihrab}

Dari bagian dalam Masjid Merah, pada dinding bagian Kiblat, pada tempat pengimaman terdapat elemen ceruk kecil, bagian inilah kemudian dikenal dengan 
elemen mihrab. Menilik sejarah terbentuknya mihrab di masjid, mihrab pertama dipakai adalah mihrab yang dipasang di Masjid Qubbah al-Sakhra, atau Al-kuds di Jerusalem.

Dari waktu ke waktu, mihrab mengalami perkembangan wujud tanpa mengalami perkembangan fungsi. Mihrab yang awalnya merupakan bentuk dekoratif pada dinding kiblat, berkembang menjadi ruang pengimaman yang dikenal sebagai Maqsura. Pada Masjid Merah Panjunan tempat pengimaman ada 2 buah, pertama tempat pengimaman yang hanya dipakai 2 kali dalam setahun, yakni pada saat hari raya Idul Fitri dan hari raya Idul Adha yang berada di bagian dalam. Adapun yang satu lagi, yang semula sebagai pintu masuk ke ruang utama dipakai untuk tempat pengimaman pada shalat berjamaah masyarakat umum. Kekukuhan dan keteraturan yang mendominasi citra luar arsitektur masjid, dipadukan dengan kelapangan dan keindahan suasana ruang dalamnya mencerminkan sikap lahir dan batin yang harus dimiliki oleh umat Islam. Kemudian upaya pencapaian fisik itu dikunci dengan mengarahkan orientasi bangunan ke satu titik: Kiblat utama, yaitu Ka'bah Baitullah. Seluruh susunan itu menuju satu pesan: satu titik keesaan Allah. Arsitektur masjid seakan memberi contoh, betapa upaya sepenuh daya tersebut seakan berakhir tunduk dan berserah diri kepada sang Khaliq. Di balik perintah untuk menghadap wajah ke Kiblat yang satu, Ka'bah, memiliki kedalaman makna. Ka'bah Baitullah diyakini dipilih oleh Allah sebagai awal tempat ibadah di bumi.

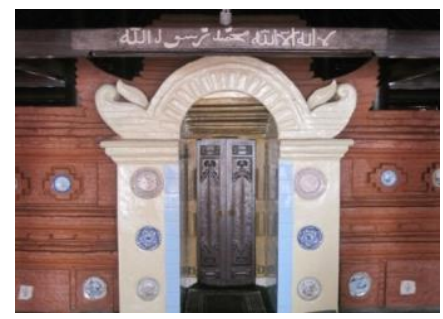

Foto 6. Mihrab bagian luar Masjid Merah. (Sumber: Dok. Pribadi, 2011)

\section{Menara}

Minaret mulai dikenal kegunaannya dalam arsitektur masjid ketika pemerintahan Bani Umayyah di Damaskus. Dalam tampilan bentuk menara, pengaruh tradisi setempat yang terkait dengan gagasan budaya dan tingkat keterampilan mengolah bahan yang dikuasai oleh masyarakat ikut mengambil peranan besar. Ragam bentuk menara dari satu bentuk budaya dengan daerah lain akan berbeda. Masing-masing wilayah menyumbangkan kreasi bagi kekayaan arsitektur Islam.

Pada Masjid Merah menurut nara sumber yang kami temui bahwa pernah dibangun bentuk menara, tetapi menyerupai bentuk bangunan gereja, sehingga masyarakat Panjunan tidak menyetujuinya. Kemudian atas dasar kesepakatan para pemuka agama bangunan menara di bongkar kembali. Sebagai ganti menara Masjid Merah menggunakan besi panjang sebagai penyanggga loudspeaker dalam menyuarakan azan.

\section{Portal}

Pada struktur bangun Masjid Merah Panjunan, kolom-kolom bangunan ditopang oleh 17 pilar bulat untuk menopang kubah berbentuk piramida. Makna filosofi yang terkandung dalam pembuatan 17 pilar utama adalah sebagai implementasi kewajiban melaksanakan shalat dari seorang muslim untuk menjalankan syariat Islam. Dalam melaksanakan kewajiban shalat lima waktu terdapat 17 rakaat yang diwujudkan oleh pendiri Masjid Merah ini sebagai simbol agar para muslim menegakkan salah satu rukun Islam. 


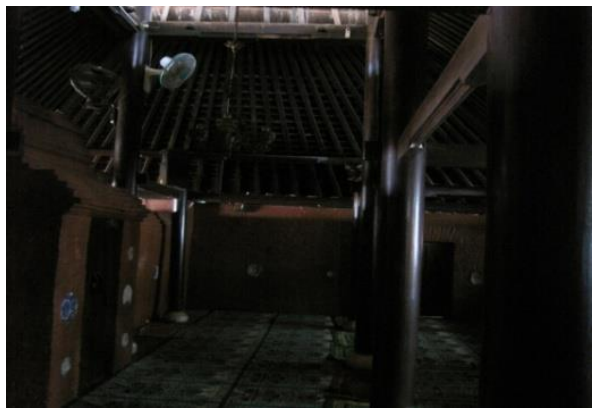

Foto 7. Portal Penyangga Kubah. (Sumber: Dok. Pribadi, 2011).

\section{Mimbar}

Pada awal dibuatnya mimbar di Masjid Nabawi, jumlah pengikut dan para sahabat Nabi Muhammad Saw. telah mencapai 100 orang lebih. Mereka berkumpul untuk mendengarkan nasihat yang diberikan Nabi Saw., akan tetapi bagi para sahabat yang duduk pada shaf bagian belakang tidak bisa mendengarkan suara Nabi Saw. dengan sempurna, selain itu penglihatan mereka juga terhalang oleh shaf yang di depan. Kemudian para sahabat mengusulkan agar Nabi Saw. duduk lebih tinggi dari para jamaahnya, dengan menaruh undakan kayu sederhana sebagai tempat Nabi Saw. duduk. Beda tingginya pun hanya tiga undakan saja dari tanah. Di atas benda tersebut, kemudian Nabi Saw. sering duduk memberikan khutbah-khutbahnya (Fanani, 2008:152).

Benda inilah di kemudian hari dikembangkan dan dikenal sebagai mimbar. Mimbar pada Masjid Merah Panjunan ditempatkan di sebelah kanan pengimaman. Mimbar ini terbuat dari kayu jati dan diselimuti kain putih, untuk menjaga kebersihan dan ketahanan bahanbahannya agar tidak cepat lapuk.

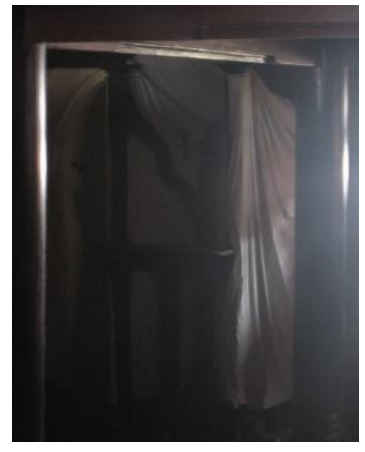

Foto 8. Mimbar

(Sumber: Dok. Pribadi, 2011)

\section{Tempat Wudhu}

Pada awalnya tempat wudhu para jamaah berada sebelah kanan bangunan masjid (Foto 9), kemudian karena ruangan dalam sudah tidak bisa menampung jamaah jika pelaksanaan sholat Idul Fitri dan Idul Adha, selain itu juga bekas tempat wudhu difungsikan sebagai selasar tempat jamaah beristirahat.

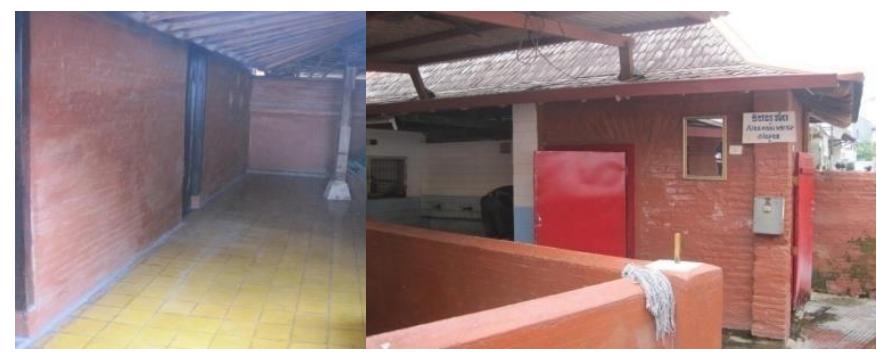

Foto 9. Bekas tempat wudhu (kiri) dan tempat wudhu sekarang (kanan).

(Sumber: Dok. Pribadi, 2011)

Penyebaran ajaran Islam di tanah Jawa mencapai puncaknya pada era Wali Sanga. Mulai dari Sunan Ampel Denta di Gresik Jawa Timur sampai Sunan Gunungjati di Cirebon Jawa Barat. Dari sembilan wali Allah tersebut Sunan Kalijaga merupakan wali penyebar ajaran Islam yang paling peduli terhadap kesenian yang ada di tanah Jawa. Beliaulah yang pertama kali mempunyai ide menciptakan bedug di masjid, dengan memerintahkan muridnya Sunan Tembayat untuk membuat bedug di daerah Semarang. Fungsi bedug adalah guna memanggil orang untuk pergi menunaikan shalat Jum'at. 


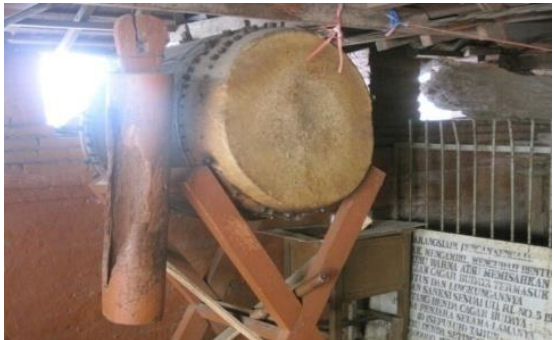

Foto 10. Bedug dan kentongan di Masjid Merah.

(Sumber: Dok. Pribadi, 2011)

\section{Ornamen Dekorasi}

Arsitektur Islam bukan hanya diramaikan oleh banyaknya atribut sekunder yang diperhalus semirip aslinya berasal dari tradisi lokal. Ornamen dekoratif banyak berkembang dalam arsitektur Islam sejalan dengan doktrin keagamaan yang melarang duplikasi makhluk yang mampu berjalan. Di antara berbagai ragam hias yang merupakan ornamen yang ditampikan pada dinding Masjid Merah adalah tumbuhan berbentuk bunga matahari. Gambar ini merupakan relief yang menonjol pada dinding tembok pembatas bangunan. Pada hiasan tembok pembatas gambar diapit oleh hiasan piringpiring porselin yang sudah hilang, sekarang hanya terlihat cekungancekungan sebagai tempat piring porselin.

Simbol yang terdapat dalam relief tersebut mempunyai makna bahwa matahari menggambarkan sinar penerangan atau pun pencerahan bagi seluruh umat manusia untuk menggapai keimanan dan ketakwaaan kepada Allah SWT. Jika disimak makna ini, maka dapat dikatakan bahwa dari tempat inilah kita belajar, memahami, mengimani, kemudian mengamalkan semua ajaran Islam.

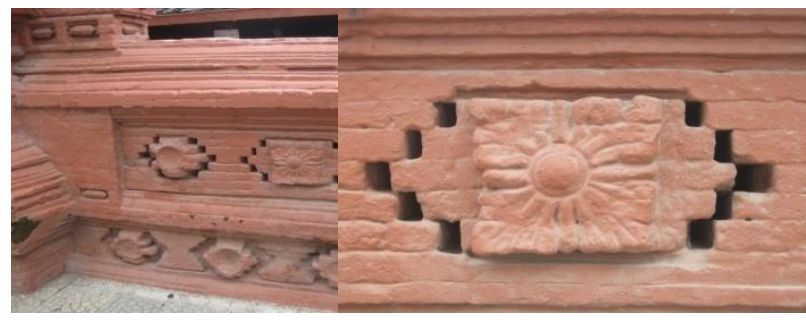

Foto 11. Bentuk ornamen dinding (kiri) dan relief bunga matahari (kanan).

(Sumber: Dok. Pribadi, 2011)

Selain pada pagar tembok atau kuta kosod bagian luar, di bagian dalam terdapat tembok sebagai pembatas antara ruang luar dengan ruangan dalam. Ruangan luar dipakai oleh orang yang shalat setiap hari, sedangkan ruangan dalam hanya dipakai atau dibuka untuk shalat Idul Fitri dan Idul Adha. Pada tembok pembatas terdapat ornamen berupa hiasan piring-piring porselen untuk memperindah suasana dalam masjid tersebut. Piring-piring tersebut merupakan hadiah kaisar Tiongkok kepada Sunan Gunungjati sewaktu beliau menikah dengan putri Ong Tien. Penempatan piring-piring tersebut sebagai ornamen Masjid Merah, menandakan bahwa ajaran Islam tidak menabukan hasil budaya asing.

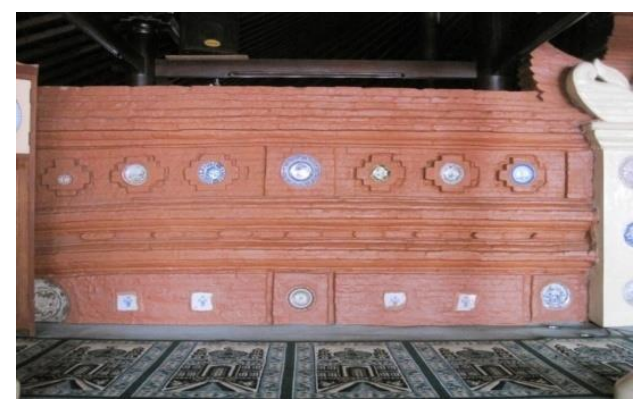

Foto 12. Ornamen pada Dinding Pembatas. (Sumber: Dok. Pribadi, 2011)

Contoh dari beberapa ornamen piring yang menjadi hiasan dinding Masjid Merah Panjunan, bentuk lukisan dalam piringnya bergambar floral, seperti bunga matahari dan lainnya, menandakan betapa kayanya imajinatif para pelukis di kala itu. Selain unsur keindahan yang ditonjolkan, unsur makna dari lukisan tersebut turut memberi warna tersendiri. Unsur matahari 
yang selalu memberikan cahaya dan penerangan divisualisasi dalam bentuk gambar di atas piring. Secara kodrati sinar matahari memberikan warna kehidupan bagi semua makhluk hidup di alam semesta ini, dan secara filosofi sebagai cahaya penerang bagi umat manusia untuk mencari kebenaran yang hakiki. Itulah sebabnya bentuk relief-relief bunga matahari banyak digunakan pada masjidmasjid di Indonesia, seperti Masjid Demak di Demak, Masjid Agung Banten Lama di Banten, Masjid Agung Sang Cipta Rasa di Cirebon.

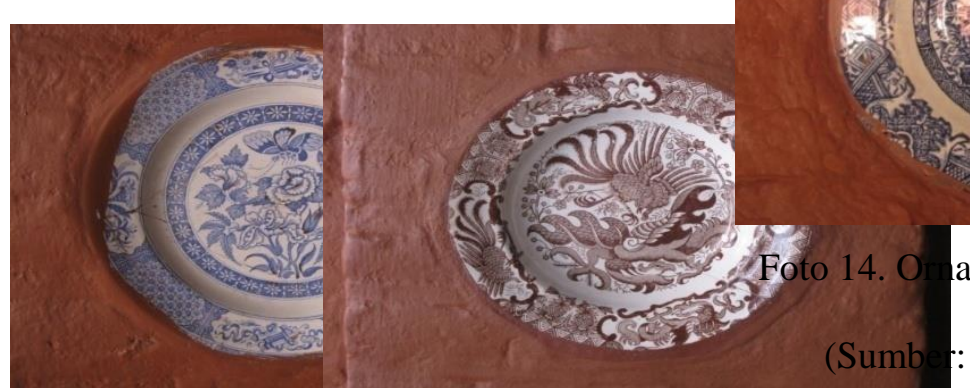

arsitektur Romawi, Mesir, Siria, Spanyol, India atau pun dari budaya setempat. Dengan demikian makna yang terkandung di dalam ornamen-ornamen yang terdapat di Masjid Merah mengisyaratkan bahwa Islam tidak melarang hasil daya kreativitas manusia meskipun bukan dihasilkan oleh kaum muslimin, sepanjang tidak bertentangan dengan hukum-hukum Islam.

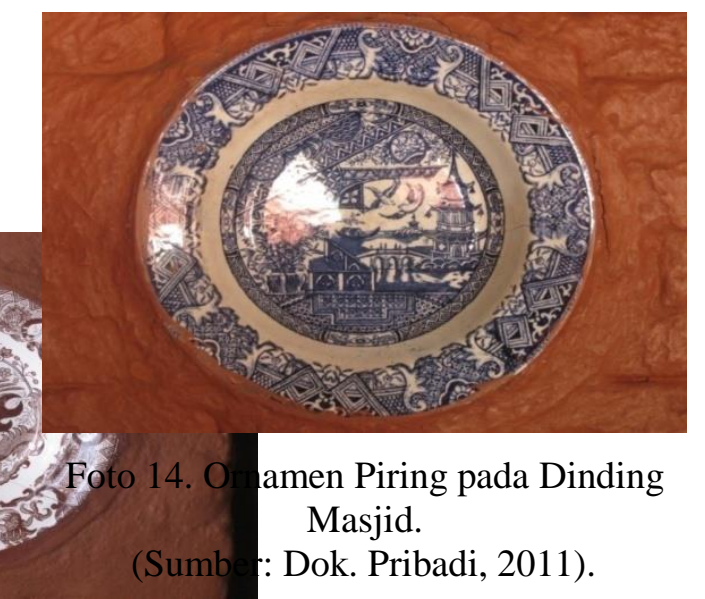

Foto 13. Piring bergambar bunga (kiri) dan piring bergambar flora (kanan).

(Sumber: Dok. Pribadi, 2011)

Selain ornamen piring yang bergambar bunga matahari dan floral lainnya, terdapat juga piring yang bergambar mirip menara pagoda di Cina, yang dibangun pada abad ke-8 M. Selain itu terdapat gambar perahu Jung yang merupakan ciri khas perahu bangsa Cina. Fungsi dari ornamen ini untuk memenuhi unsur keindahan dari sebuah masjid. Meskipun awalnya Nabi Saw. membuat masjid sebagai tempat beribadah sangat sederhana, tetapi dengan perkembangan zaman dan daya kreativitas yang ada pada kaum muslimin, maka pembangunan masjid dibuat dengan seindah mungkin dengan ornamen-ornamen yang tersedia di daerah tersebut. Seperti diketahui bahwa pembangunan masjid bukan dari budaya Arab saja, tetapi gaya pembangunan/ arsitektur masjid banyak mengadopsi dari unsur-unsur lain, misalnya pengaruh
Bentuk ornamen lain yang menghiasi Masjid Merah, pada tiang/soko penyangga pada bagian atas atau pun bagian bawah menggambarkan relief bunga padma (bunga teratai). Bentuk ornamen relief ini berasal dari profil singgasana sang Budha Gautama yang berbentuk bunga padma atau dipakai juga untuk landasan bangunan stupa. Bentuk relief seperti ini berada pada ruangan luar (bangunan tambahan) yang dipakai sholat setiap hari. Seperti halnya oranamen lain, ragam hias padma ini selain mempunyai fungsi sebagai unsur keindahan, juga mempunyai makna kesucian, keluhuran budi pekerti, kekuatan dan kekokohan. 

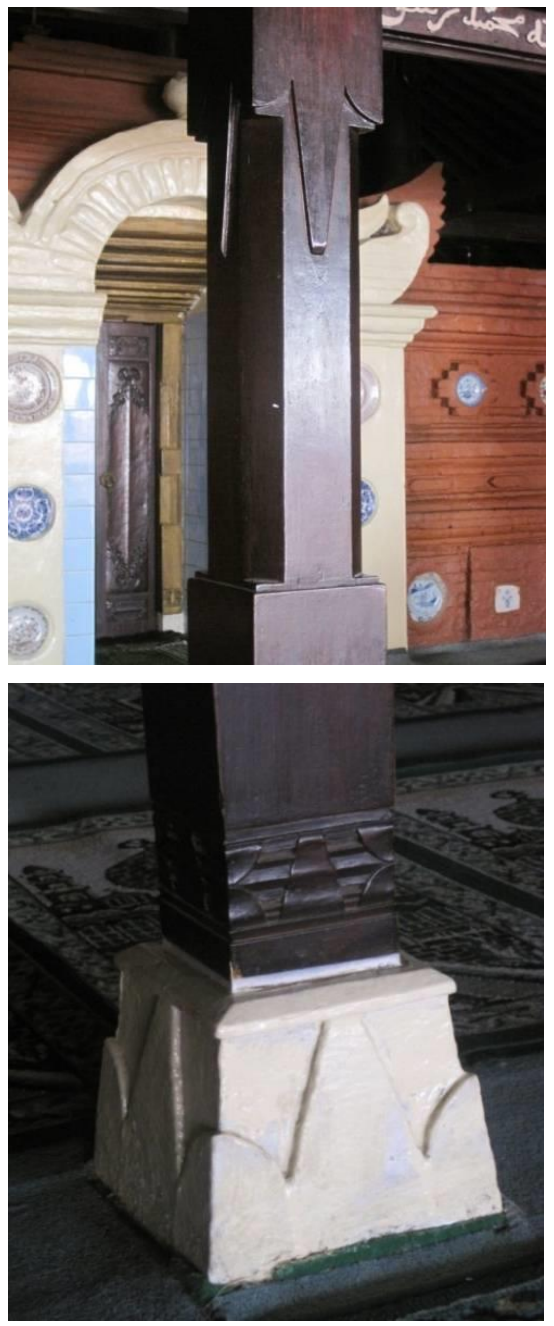

Foto15. Padma pada Tiang Penyangga (atas) dan Padma pada Landasan Tiang (bawah) (Sumber: Dok. Pribadi, 2011)

Ornamen buah labu yang terbuat dari batu dan bata merah ditempatkan sedemikian rupa sehingga membentuk tipe buah labu. Ornamen ini berfungsi sebagai penyanggga pilar/tiang yang terdapat pada ruang utama (dalam) dan ruang luar sebelah barat dan sebelah timur. Ornamen ini dibuat dengan ukuran yang berbeda. Penempatan disesuaikan dengan ukuran saka yang ada. Ornamen yang ada sebagai landasan kayu penyangga dikombinasikan antara bentuk labu dengan bentuk padma. Pada bentuk labu sebagai penyangga banyak dibuat di dalam ruang utama, sedangkan bentuk padma banyak dibuat pada ruangan tambahan. Seperti pada ruang tambahan kebanyakan dibuat dengan landasan bunga padma. Pada pembuatan ornamen buah labu kayu penyangga/sokoguru berbentuk bulat sedangkan pada landasan kayu penyangga (pilar)-nya berbentuk segi empat. Fungsi dari landasan ini selain dilihat dari segi estetika, juga dilihat dari bentuk keserasian antara bentuk pilar dan bentuk landasan tempat pilar itu berdiri. Maknanya dari pembuatan ini adalah masyarakat yang masih dikuasai oleh alam cenderung menerima bentuk-bentuk dan bahan secara alami. Kemudian setelah masyarakat mengembangkan teknologi untuk mengatasi alam, cenderung akan mengubah bentuk dan bahan dengan turunannya dan diolah dalam bentuk olahan mereka sendiri. Misalnya bentuk bulatan, bahan kayu, batu, bata tidak harus sempurna, dapat berbentuk segi tiga, bujur sangkar atau pun persegi, begitu juga dengan bahan olahan plester, beton dan kaca. Pembentukan ini akan dikaitkan dengan filosofi nilai-nilai keagamaan.

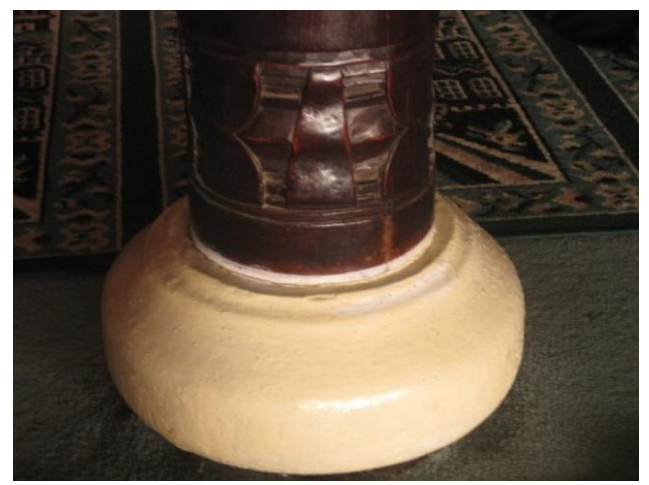

Foto 16. Buah Labu pada Landasan Tiang Penyangga.

(Sumber: Dok. Pribadi, 2011)

Ada beberapa ornamen belah ketupat dalam arsitektur Masjid Merah, di antaranya pada dinding sebelah utara, barat, dan selatan. Ornamen ini berfungsi sebagai ventilasi atau lubang angin untuk pertukaran udara dari dalam dan sebaliknya, ornamen ini berada di ruangan utama dan ruangan luar dari masjid. 
Ragam hias ini menyerupai ragam hias salib Portugis yang berbentuk belah ketupat. Ornamen salib Portugis yang dipakai pada ornamen masjid merupakan pengaruh dari kebudayaan agama Kristen. Simbol dari ornamen ini mempunyai makna daur kehidupan manusia, yang terdiri atas empat alam, yakni alam arwah, alam kandungan, alam dunia, dan alam akhirat. Kemudian melihat dari terciptanya wujud manusia terbangun dari empat anasir utama, yaitu tanah, air, udara, dan api. Kemudian ada empat unsur utama dalam pendekatan tasawuf yaitu syariat, tarekat, hakekat, dan marifat, yang merupakan empat unsur utama dalam pendekatan tasawuf yang menyatu dalam prinsip ahwal dan maqomat, menuju singgasana Tuhan.

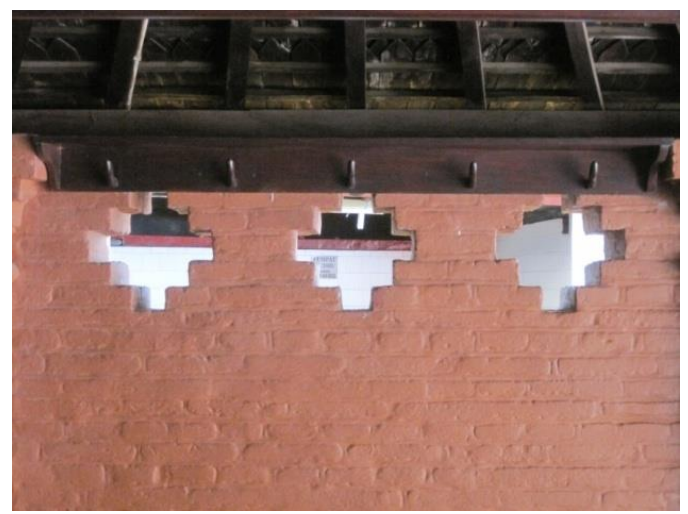

Foto 17. Ornamen Salib Portugis (Sumber: Dok. Pribadi, 2011)

Dalam pembentukan wujud Masjid Merah Panjunan, dan masjid-masjid yang sezaman, hampir setiap detailnya mengandung rekaman cerita yang menarik tentang bagaimana semangat keimanan memandu terwujudnya masyarakat Islam. Hampir 28 tahun sejak berdirinya Masjid Pejlagrahan, para wali telah memberi contoh bagaimana kekuatan persaudaraan ikut menentukan wujud masjid. Tersusunnya bangunan masjid, hadirnya komponen pembentuk sosok masjid. Satu per satu, berdasarkan kebutuhan praktis saat itu, menggambarkan terbentuknya persaudaraan Islam dalam kenyataan kehidupan sehari-hari yang sederhana, wajar, dan alamiah.

\section{PENUTUP}

Pembangunan Masjid Merah berkaitan dengan migrasi keturunan Arab ke Cirebon sekitar abad ke-14. Pada tahun 1480 M, Syekh Syarif Abdurrakhman (keturunan bangsawan Arab yang turut bermigrasi ke Cirebon) membangun masjid /surau di daerah Panjunan, dikenal dengan nama Masjid Merah Panjunan, terletak di kelurahan Panjunan. Masjid ini dikenal dengan nama Masjid Merah, karena dinding masjid ini dibangun dari susunan bata merah, sedangkan nama Panjunan menunjuk pada kampung dimana masjid itu berada. Kata Panjunan berasal dari kata "anjun", artinya daerah dimana penduduknya mempunyai pekerjaan membuat gerabah dari tanah liat. Masjid Merah ini merupakan masjid yang kedua di Cirebon setelah Masjid Pejlagrahan yang dibangun oleh Pangeran Cakrabuwana. Pada tahun 1549 sewaktu Kesultanan Cirebon diperintah oleh panembahan Ratu, halaman Masjid Merah dipagar dengan kuta kosod, pada pintu masuk dibangun dengan bentuk candi bentar dengan pintu panel jati berukir.

Arsitektur Masjid Merah sebagai artefak budaya, ornamen pada elemenelemennya menjadi objek yang pantas dicermati yang punya kaitan dengan kejadian, peristiwa, atau tema penting di saat ia dibangun. Kemudian jika dilihat ornamen atau ragam hias yang digunakan di dinding Masjid Merah didominasi oleh piring-piring porselin, merupakan hadiah dari kaisar Cina untuk Sunan Gunungjati. Gaya arsitektur pembangunan Masjid Merah Panjunan adalah menyatukan tiga kebudayaan besar (Cina, India, Arab/Islam).

Arsitektur mencerminkan tingkat penguasaan masyarakat terhadap pengetahuan. Pengetahuan arsitektur akan terus berkembang, seiring dengan masyarakat yang semakin maju, dan akan 
mengacu pada banyak hal. Kajian tentang struktur bangunan, konstruksi bahan, udara, pencahayaan, suara dan tatacara merancang sampai pengoperasian bangunan. Arsitektur adalah sebuah refleksi potensi ruhani yang hidup dalam masyarakat. Karya arsitektur dapat dijadikan media untuk berkomunikasi lewat bahasa lambang dalam mengungkapkan bentuk, ruang dan ornamen dalam sebuah bangunan masjid.

Arsitektur Masjid Merah Panjunan merupakan rekaman nyata dari ekspresi, intelektual, dan spiritual yang diwujudkan dalam bentuk fisik. Di dalamnya banyak dijumpai kode kultural yang telah diterima secara umum sebagai bagian dari identitas kelompok. Pada elemen ruang, bentuk, dan struktur terdapat tanda-tanda semacam ini, bukan saja menjadi ciri waktu dan sejarah, namun sekaligus mengandung esensi pesan yang terkait di ujungnya kepada Tuhan. Hal ini diperlukan kecermatan agar dapat membaca tanda-tanda, menafsirkan, dan mencari maknanya untuk sampai pada inti pesan yang dikandungnya. Arsitektur masjid dapat dilihat sebagai sebuah urutan lengkap aktivitas dari beribadah. Penempatan setiap elemen tempat wudhu, menara, mihrab, mimbar mewakili aktivitas tersebut. Dalam tahap ini arsitektur masjid dirasakan hadir praktis, dalam tataran fungsi primernya.

Masjid Merah merupakan tempat ibadah sholat bagi kaum muslimin, yang dibangun pada tahun 1480 dan sudah ditetapkan sebagai cagar budaya, maka seyogyanya Pemerintah Daerah memperhatikan dan memelihara sebagai warisan budaya. Oleh karena itu perlu adanya pemeliharaan berkesinambungan yang diharapkan dapat dijadikan sebagai objek wisata ziarah, sehingga menjadikan objek pendapatan daerah minimal untuk kesejahteraan juru pelihara.

\section{DAFTAR SUMBER}

Abdullah, Taufik (ed).1974.

Islam di Indonesia. Jakarta: Tinta Mas.

Al-Murtadho. Syayid Husein.1999.

Keteladanan dan Perjuangan

Walisongo dalam Menyiarkan Agama Islam di Tanah Jawa. Bandung: Pustaka Setia.

Atja. 1972.

Purwaka Tjaruban Nagari (sedjarah

Mula Djadi Keradjaan Tjirebon).

Djakarta: Ikatan Karyawan

Museum.

Cipto Prawiro, Abdulah.1986.

Falsafat Jawa. Jakarta: Balai

Pustaka.

Dinas Kebudayaan dan Parawisata Kota Cirebon. 2006.

Potensi Wisata Kota Cirebon. Cirebon: Neo Technologi.

Fanani,Achmad. 2008.

Arsitektur Masjid. Jogyakarta: Bentang Pustaka.

Graaf, H.J. dan Th.G.TH.Pigeaud. 1986.

Kerajaan-Kerajaan Islam di Jawa : Peralihan dari Majapahit ke Mataram. Jakarta: Grafisi Pers.

Hamka. 1976.

Sejarah Umat Islam. Jakarta: Bulan Bintang.

Khalim, Samidi. 2008.

Islam \& Spiritualitas Jawa. Semarang: RaSAIL.

Koentjaraningrat.1994.

Kebudayaan Jawa. Jakarta: Balai Pustaka. 
Peursen, C.Avan. 2000.

Strategi Kebudayaan. terj. Dick Hartoko. Yogyakarta: Kanisius.

Rahimsyah,MB,AR. 2002.

Legenda dan Sejarah Para Walisanga. Surabaya: Amanah.

Rochani, Ahmad Hamam. 2008.

Babad Cirebon. Dinas Kebudayaan dan Pariwisata Kota Cirebon.

Salam, Solihin. 1974.

Sekitar Wali Sanga. Kudus: Menara Kudus.

Subagya, Rachmat. 1981.

Agama Asli Indonesia. Jakarta: Sinar Harapan.

Suchri Hidayat, Raden. 2008.

Sejarah Carruban Kawedar.

Cirebon: Badan Komunikasi

Kebudayaan dan Pariwisata

Kabupaten Cirebon.

Sucipto, Hadi. 1979.

Babad Cirebon. Jakarta: Proyek Penerbitan Bacaan dan Sastra Daerah, Depdikbud.
Sulendraningrat, P.S. 1972.

Purwaka Tjaruban Nagari. Jakarta: Bhatara. 1984.

Babad Tanah Sunda, Babad Cirebon. Cirebon.

Wahyudi,A. dan A. Khalid. 1985.

Kisah Walisongo Para Penyebar Agama Islam di Tanah Jawa.Yogyakarta.

Webster's New Twentieth Century Dictionary (Second Edition). 1980. USA: William Collins Publishers.

Yatim, Badri. 1993.

Sejarah Peradaban Islam. Jakarta: Grafindo Persada. 